\title{
LAICIDADE EM DISPUTA: UM ESTUDO A PARTIR DA APROVAÇÃO DO ENSINO RELIGIOSO CONFESSIONAL NO STF
}

\author{
Secularism in Dispute: A Study from the Approval of Confessional Religious Education in \\ the Supreme Federal Court
}

Luiz Eduardo Valiengo Berni ${ }^{1}$

\section{Resumo}

Tendo por tema a laicidade e o Ensino Religioso confessional, este trabalho objetivou a análise dos modelos de laicidade em disputa no Estado brasileiro, a partir dos votos, do relator e revisor, no Supremo Tribunal Federal (STF), no julgamento da Ação Direta de Inconstitucionalidade (ADI - 4439, de 2010). Os resultados apontam para paradoxos no modelo de laicidade brasileira. Conclui-se que existem dois modelos em disputa (laicidade com total separação estado e igreja; e laicidade com a colaboração igreja-estado); com adoção do Ensino Religioso Confessional oficializado, ampliam-se riscos à manutenção da diversidade religiosa, sobretudo dos grupos minoritários.

Palavras-chave: Laicidade, Ensino Religioso Confessional, Religião, Diversidade Religiosa

\begin{abstract}
Secularism and confessional religious education are the themes of this paper, with the aim of analyze the secular models in dispute in Brazil, based on the votes of the rapporteur and reviewer, at the Supreme Federal Court, in the judgment of the direct action for the declaration of unconstitutionality (ADI - 4439, 2010). The results point to paradoxes in the Brazilian secular model. It is concluded that there are two models in dispute (secular collaboration state-church and secular total separation church and state). The adoption of official Confessional Religious Education, increase the risks to religious diversity especially for minority groups.
\end{abstract}

Key words: Religious Education, Secularity, Religion, Religious Diversity

\section{INTRODUÇÃO}

Este breve estudo de base bibliográfica qualitativa objetiva tornar claro a disputa entre os modelos de laicidade presentes no Estado brasileiro. Toma por base a discussão e adoção do Ensino

\footnotetext{
${ }^{1}$ Psicólogo (CRP 06/35863); Mestre em Ciências da Religião (PUC-SP); Doutor de Psicologia (IP-USP);

Pesquisador do Ateliê de Pesquisa Transdisciplinar (APTD). E-mail: levberni@hotmail.com
} 
Religioso Confessional, a partir da rejeição pelo Supremo Tribunal Federal, da Ação Direta de Inconstitucionalidade (ADI 4439/10) impetrada pela Procuradora Geral da República.

Desta forma, no intuito de contribuir com a reflexão no campo, a partir da qual se justifica esse trabalho, inicia-se apresentando um cenário nacional e internacional referente ao status das crenças religiosas, de modo a situar o Brasil nesse contexto. Na sequência, apresenta-se o complexo campo da laicidade e da secularização, depurando definições e significados, onde se procura localizar os fundamentos da laicidade brasileira. Depois aprofunda-se o olhar sobre a laicidade, a partir da instituição do paradoxo do Ensino Religioso num recorte histórico para, por fim, apresentar-se a disputa pelo modelo de laicidade a partir da questão do Ensino Religioso Confessional, aprovado pelo STF, bem como apresentando desafios propostos com essa aprovação.

\section{O CENÁRIO DAS CRENÇAS NO BRASIL E NO MUNDO E OS CONCEITOS BÁSICOS DO CAMPO}

Em 2015 a WIN Gallup International, uma conhecida agência de pesquisa, publicou uma investigação (survey) que entrevistou 65 mil pessoas, em 65 países estabelecendo um ranking daqueles que são mais (e menos) "crentes" do mundo. A investigação concluiu que 63\% da população mundial acredita em Deus e $11 \%$ declara-se ateia (RUIC, 2015). O Brasil ocupa o $23^{\circ}$ lugar no ranking dos mais crentes, à frente da Argentina, que ocupa a 30ª posição. Dentre os

primeiros 20 lugares situam-se países no Leste europeu, na África e Ásia (Oriente Próximo), nações em desenvolvimento ou subdesenvolvidas. Dentre os menos crentes estão países do Extremo Oriente, como China e Japão ( $1^{\circ}$ e $2^{\circ}$ lugares), e países da Europa como o Reino Unido $\left(7^{\circ}\right)$, e Israel ( $8^{\circ}$ menos crente).

Abumanssur (2016), baseado em Gritti (2004), apresenta um panorama sobre a adoção de "religião oficial" em diferentes estados nacionais. O autor informa que "das quase duzentas nações existentes, 49 reconhecem em suas constituições uma igreja ou religião oficial”. Reportando, também, dificuldade em estabelecer um parâmetro comum, pois não há uma definição unívoca sobre o que vem a ser religião oficial. Nas Américas, por exemplo, todos os países, com exceção 
do México e Uruguai, fazem menção a Deus no preâmbulo de suas constituições" (ABUMANSSUR, 2016, p. 21-22).

O Brasil convive há séculos com a presença de símbolos religiosos em suas instituições. O crucifixo é tradicionalmente encontrado nas paredes de instituições do Estado brasileiro, tendo sua presença contestada por alguns (SARMENTO, 2007). A tentativa de serem retirados tais símbolos das paredes institucionais falhou em 2009, vedada no $3^{\circ}$ Plano Nacional de Direitos Humanos (BRASIL, 2009), sob alegação de que "fazem parte da cultura".

\section{MODELOS DE LAICIDADE E A LAICIDADE BRASILEIRA}

Apesar de ser relativamente recente, o conceito de laicidade é bastante complexo, talvez seja mesmo problemático, como se verá, pois, se trata de um termo de difícil apreensão, que se pretende acadêmico, e que possibilita diferentes tipos de interpretação (ABUMANSSUR, 2016).

Mariano (2011) apresenta os conflitos teóricos no campo e destaca os elementos que ligam os termos laicidade e secularização. Mariano (2011, p. 243), afirma a multiplicidade do uso do termo como conceito, teoria, paradigma e fenômeno, além de destacar a preferência pelo uso do termo "secularização" na literatura anglo-germânica, enquanto que na literatura latina (francês, espanhol e português) este termo divide o campo como o termo "laicidade" e suas derivações.

A palavra laicidade emerge do campo religioso (cristão) e associa-se à palavra leigo. Rizzardo (2010) esclarece que os termos leigo e laico surgiram como sinônimos, porém, hoje são definidos como antônimos.

Antigamente, ambos se referiam a uma pessoa que não fazia parte do clero, um secular. Ou ainda - um significado que continua em vigor -, a alguém que está por fora da realidade. Ultimamente, no campo da fé, cada um deles adquiriu uma acepção precisa: "laico" passou a se opor a religioso, e "leigo", de acordo com o Concílio Vaticano II, "é o fiel que, incorporado a Cristo pelo batismo, exerce, em seu âmbito, a missão de todo o povo cristão na Igreja e no mundo" (RIZZARDO, $2010)^{2}$.

A etimologia da palavra laicidade vem do grego laikós, precisamente do substantivo laós que significa povo que, como se pode observar, revela pouco sobre sua dimensão conceitual. Para

\footnotetext{
2 Apesar dessa diferenciação, no ano de 2018 a Igreja Católica comemorou o "Ano do Laicato para estimular o protagonismo cristão do leigo" http://www.cnbb.org.br/ano-do-laicato-intensificara-o-trabalho-para-que-cristaosleigos-e-leigas-sejam-sal-e-luz-na-igreja-e-na-sociedade/
} 
compreendê-la é preciso recorrer a um recorte histórico (PAIVA, 2016), o que nos remete à Igreja Católica, como já se afirmou, que usa o termo em sua vertente latina - laicus - para diferenciar o povo (de Deus) do clero. Portanto, laico é “o povo de Deus" - rebanho - que é guiado pelos pastores, clérigos - "servos de Deus"3.

Rios et al (2017), citando Oro (2008), afirma que o termo laicidade é um neologismo do francês, "datado de 1871, no seio do republicanismo da liberdade de opinião num contexto que marca oposição à monarquia e à vontade divina como fundamentos e organização da sociedade" (p. 162).

Desta forma, num primeiro nível de definição, pode-se afirmar que laicidade é um princípio, uma característica ou diretriz do Estado ocidental democrático, que rege as relações entre a Igreja (a religião) e o Estado (a política), ou, de acordo com a Declaração da Laicidade no século XXI, a "harmonização" de três princípios: "liberdade de consciência prática (religiosa ou não)"; "autonomia da política em relação às normas religiosas", e "ausência de discriminação" contra tais propostas e seus praticantes.

O conceito de laicidade fundamenta-se, também, na Secularização, ou separação entre as coisas da religião das coisas do Estado. "Século" deve ser compreendido aqui como sinônimo de mundo material:

O termo secular deu origem à secularização, expressão que designa o processo de mudança pelo qual a sociedade deixa de ter instituições legitimadas pelo sagrado, baseadas no ritualismo e na tradição, tornando-se cada vez mais profana (ou secular), baseada na individualidade, na racionalidade e na especificidade (OLE, s.d.).

A secularização foi (é) um processo histórico de separação da simbiose existente entre o Estado e a Religião (ALVES, 2018). Esse processo tem seu marco inicial no desenvolvimento da ciência (modernidade) e no fortalecimento de instituições, como a escola pública, por exemplo (RIVERA, 2010). A secularização estabeleceu "uma diferença entre as esferas pública e privada, e religião passou a dizer respeito à esfera privada. Um processo de emancipação da vida pública em relação à tutela do Estado" (ABUMANSSUR, 2016, p. 18). Este processo fortaleceu o Estado,

\footnotetext{
${ }^{3}$ Essa imagem é muito comum no discurso religioso; é emblemática no tocante à questão da autonomia/heteronomia, visto que o rebanho não tem autonomia para se autoconduzir, necessitando de um guia, um pastor.
} 
e não esvaziou a religião de seu lugar social, pelo contrário, na América Latina as Igrejas continuam fortes (RIVERA, 2010).

Surge, portanto, a pergunta: qual o atual lugar da Religião na sociedade, seria ele de foro privado ou público? ${ }^{4}$

As distinções entre os conceitos de público e privado são fundamentais para a laicidade do Estado e envolvem, não raro, muita ambiguidade. Tais termos podem ser usados para distinguir Estado/Sociedade e para distinguir a vida doméstica da vida não-doméstica. Okin (2008) afirma "nessas duas dicotomias, o Estado é (paradigmaticamente) público, e a família e a vida íntima e doméstica são (também paradigmaticamente) privadas"5.

Outros autores, entretanto, veem a questão de forma relativizada envolvendo as dimensões públicas e privadas imbricadas uma na outra, como as camadas de uma cebola (WEINSTEIN apud OKIN, 2008).

Seja como for, a emergência de novas questões sociais, ou a revisão de conceitos com a introdução de novas dimensões conceituais/sociais, como por exemplo, a abrangência/revisão dos conceitos de sexo e de família introduzem novos graus de complexidade e de conflito à questão do público/privado.

Assim, se o Estado e, portanto, o Direito está para o público, a Sociedade, os costumes, portanto, a Moral estão para o privado. Abre-se, assim, novo paradoxo, pois a liberdade de crença e consciência - moral é (pode ser, deve ser) cerceada pelo Direito (?). Estes pontos estão no cerne do debate sobre laicidade.

Assegurar o direito coletivo às crenças implica em afirmar o direito privado à moral. Portanto, parece útil que se possa diferenciar Direito, Moral e Ética (GOLDIN, 2003), pois existem aproximações e distanciamentos entre esses conceitos, que podem gerar contradições e outros (ou novos) conflitos.

Moral e Direito se aproximam quando são compreendidos no campo normativo. A Moral, entretanto, é de foro privado e refere-se aos costumes, a valores culturais herdados, ou assumidos, independe das fronteiras geopolíticas, pois está ligada a grupos culturais, étnicos, que partilham

\footnotetext{
${ }^{4}$ Esta questão terá desdobramentos no julgamento do Ensino Religioso Confessional no SFT, como se verá.

${ }^{5}$ Parênteses nossos.
} 
de referências comuns, por exemplo, os Cristãos, o Islã, os Iorubás, os Guaranis, etc., cuja moral (código) transcende as fronteiras nacionais ${ }^{6}$.

O Direito é de foro público do Estado (ou dos Estados), pois estabelece um regramento acordado no debate político e está circunscrito, portanto, às fronteiras geopolíticas da nação (território, país, estados, municípios), valem, portanto, apenas para áreas especificamente delimitadas. Há, entretanto, acordos supranacionais que garantem Direitos Coletivos, como é o caso da Declaração Universal dos Direitos Humanos (DUDH).

Existe, portanto, um jogo entre o Direito e a Moral que gera uma série de paradoxos e tensões além dos que já foram mencionados. Neste sentido, o Direito assume um caráter público, pois abrange a todos no território de sua jurisdição, enquanto a Moral um caráter privado principalmente numa sociedade multicultural como a brasileira - pois diz respeito aos diferentes grupos que compõem a sociedade que pode transcender o território do direito, como é o caso das grandes confissões de fé.

A Ética, por sua vez, é da ordem da reflexão filosófica sobre a existência e os valores, ou, como afirma Vásquez (1997), "a ciência da moral”. Refere-se à ação de construção do humano, seu foco, portanto, não se refere ao estabelecimento de regras, mas à compreensão dos elementos que explicam como as regras são estabelecidas e, neste sentido, busca explicar o Direito e a Moral ${ }^{7}$.

A origem das regras sociais se perde na aurora dos tempos, estando intimamente ligada à complexificação das sociedades, sofrendo, ao longo da história, muita interferência de questões transcendentais como as que se discutem no âmbito da religião. Portanto, ao se remeter ao passado, recente ou distante, pode-se observar que qualquer tipo de "direito", ou o que venha ser compreendido como tal, situa-se num contexto histórico-cultural e, portanto, possui vínculos tempo-espaciais bem definidos. Todos os direitos, assim como a moral, estão, portanto, inseridos num grande paradigma cultural, para o qual se é, normalmente, cego, pois o paradigma é um filtro que direciona o comportamento de forma inconsciente. Só se pode percebê-lo ao se buscar refletir sob o lastro de métodos rigorosos, como é o caso daqueles propostos pela filosofia na análise ética,

\footnotetext{
${ }^{6}$ No caso de confissões hegemônicas, como o Cristianismo, esses grupos transcendem em muito as fronteiras de um país.

${ }^{7}$ Há uma confusão no uso deste termo do ponto de vista profissional ao denominar as regras de conduta como "código de ética", o mais adequado seria denominar de "código deontológico". Além disso, autores populares como Cortella, Boff e Barros usam o termo Ética se referindo à Moral.
} 
mas também pela Ciência e a partir da contemplação veiculada por algumas tradições (MORIN, 1997).

Conclui-se, portanto, que o caráter paradoxal das diferentes dimensões que compõem o conceito de laicidade (secularização), tais como a diferenciação entre o público e o privado, o direito e a moral, impõe uma permanente atenção sobre a construção desse conceito ainda em debate, o que leva à existência de diferentes modelos de laicidade (MARIANO, 2011).

O ponto central na discussão sobre laicidade está na característica jurídica, ou na tipologia do Estado, isto é, nas características jurídicas adotadas pelo Estado laico. Oro (2011) enfatiza que, em todos os casos, sua estruturação se dá a partir da separação entre a Igreja e o Estado com a garantia das liberdades de crença e consciência. Não há, entretanto, unicidade nessa proposição, coexistindo, portanto, pelo menos três tipos ou modalidades de laicidade:

a) Laicidade com Igrejas de Estado - Um tipo de laicidade onde se afirma uma Igreja ou religião oficial, incorporada ao Estado, ainda que se respeitem outros tipos de crença. Esse é o caso da Inglaterra com a Igreja Anglicana; da Grécia com a Igreja Ortodoxa; da Argentina, Bolívia e Costa Rica com a Igreja Católica, entre outros;

b) Laicidade Estado-Igreja - Trata-se de uma separação onde o Estado estabelece algum tipo de relação com as Igrejas, este é o caso da Itália, Espanha, Portugal, entre outros;

c) Laicidade Igrejas e Estado - Separação total das Igrejas e o Estado sem nenhum tipo de relação entre ambos, esse é o caso da França, Hungria, Letônia, México, Uruguai, EUA, entre outros.

Há, também, pelo menos duas posturas, dois costumes sociais em relação à laicidade:

d) Laicidade intransigente ou de combate, numa postura de enfrentamento hostil de oposição à religião que visa sua exclusão do espaço público (centrada num fundamentalismo ateu);

e) Laicidade aberta, que compreende o papel social da religião enfatizando sua complementariedade em relação à ciência e o Estado (TERNISIEN apud ORO, 2011).

Para finalizar este item, cabe abordar o modelo de laicidade constitucional adotado no Estado brasileiro.

Rios et al (2017) afirmam que a "laicidade é uma resposta ao desafio da pluralidade religiosa no mundo moderno e contemporâneo" (p. 161), e tomando Bobbio (1999), situam-na mais como "método do que como conteúdo". 
Zybersztajn (2018) afirma a caracterização do Estado laico como aquele que é imparcial (e não neutro) em relação à Religião. Neste sentido a imparcialidade possibilita a ação no sentido de garantia de igualdade de condições a todas as formas de crenças, enquanto que a neutralidade poderia caracterizar inação (omissão) no caso de quebra desse princípio.

Este posicionamento é fundamental para que se garanta a manutenção do direito à liberdade de crença e consciência assegurado à população na Constituição Federal em seu $\operatorname{artigo~} 5^{\circ}$, ou das ações possíveis para se garantir esse equilíbrio.

À cultura brasileira de rara diversidade, como já se afirmou, apresenta-se um desafio que está na manutenção da pluralidade de confissões de fé, assim, o modelo assumido é de uma laicidade pluriconfessional, que prevê a cooperação em determinadas áreas, e inclui a previsão do Ensino Religioso, portanto, enquadra-se no conceito de laicidade estado-igreja.

A imparcialidade da laicidade brasileira reconhece a importância do "espaço religioso no Estado", torna, portanto, legítima a participação dos religiosos na política, defendendo o direito de todos em igualdade de condições e favorecendo a subsistência do espaço religioso com alguns benefícios, afirmando-se, também, a possibilidade de cooperação entre o Estado e as Igrejas.

Neste contexto, parece ser muito importante separar-se, como apresentam Rios et al (2017), o direito de participação política daqueles que afirmam uma fé, da imposição da fé na participação política com a supressão do direito de outros. Elemento que pode ser bastante comum quando não se reflete, como se procura fazer aqui, sobre as diferentes dimensões da Religião e da religiosidade na construção social.

Em retrospectiva, a primeira Constituição brasileira (1891) trouxe um modelo de laicidade "Estado e Igreja", ou seja, de separação total entre essas instâncias. Com o passar do tempo, sob a influência de grupos religiosos majoritários, vai se retomando um nível de interação do tipo "Estado-Igreja”, assim, na última Constituição (1988), grosso modo, há, no mínimo, uma ambiguidade, para não dizer um paradoxo.

Assim, há elementos que enfatizam a separação total Igreja e Estado, como os contidos no artigo $5^{\circ}$, que prevê a liberdade de crença e consciência e sua proteção, e, sobretudo no art. 19, que impede a subvenção das Igrejas; mas há outros que preveem alguma cooperação, portanto, o modelo Igreja-Estado, como no art. 143, que faculta a objeção de consciência ao serviço militar; e, sobretudo, no artigo 210, que compreende o Ensino Religioso como opcional, numa perspectiva 
cultural e, por fim, art. 226, que reconhece o casamento religioso com efeito civil. Esses foram aspectos que entraram na disputa que levou o STF a admitir o Ensino Religioso Confessional, que será analisado no próximo item.

\section{LACIDADE E ENSINO RELIGIOSO}

Segundo Junqueira (2011, 2013) o Ensino Religioso sempre esteve presente na Educação do Ocidente. No Brasil nasceu imerso na confissão de fé católica que, por séculos, foi sua religião oficial. O processo colonizador se deu a partir de uma educação missionária jesuítica, centrado na imposição do Ensino Religioso católico (catequização), sobre os Povos Originários, portanto, tratava-se do ensino da religião (CONCEIÇÃO, 2017).

Este modelo, que introduziu uma educação clássica e humanista no Brasil, teve grande sucesso, por exemplo, num esquema híbrido intercultural, a partir da submissão de povos indígenas ao dogma, e proporcionou o florescimento majestoso “das Missões dos 7 Povos” (SIMON, 2017).

No século XVIII, entretanto, este sistema foi desestruturado com a reforma pombalina e a expulsão dos jesuítas do Brasil. Esse foi o primeiro movimento para uma educação laica que, entretanto, parece ter sido de baixa qualidade. A despeito da introdução de uma educação laica, as instituições educacionais católicas continuaram a funcionar no país, à exceção daquelas de matriz jesuítica (SECO, AMARAL, s.d.).

A primeira Constituição brasileira de 1891 foi baseada numa laicidade do tipo Igreja e Estado, isto é, centrada no modelo de separação total. Segundo Menezes e Bahia (2013), esse modelo era fundamental para a política de atração de imigrantes, lembrando que a abolição da escravidão (Lei Áurea, 1888) se deu muito próximo à proclamação da República em 1889.

Apesar desse posicionamento não houve o fim dos privilégios e a dominância católica sobre as demais confissões de fé (MARIANO, 2011).

Assim, com o passar do tempo esse modelo de laicidade vai se afrouxando e dando lugar a um retorno a uma perspectiva do tipo Igreja-Estado, ou seja, onde há uma complementação ou colaboração entre a política e a religião.

Com o Manifesto de 1932, debateu-se de forma aprofundada a questão da laicidade escolar em meio a uma disputa entre os pioneiros "liberais" e os "católicos". A corrente católica, com o apoio da Associação Brasileira de Educação (ABE) e da figura política de Getúlio Vargas, revelou-se com maior 
poder nesse contexto histórico, e a disciplina Ensino Religioso passou a fazer parte do currículo escolar a partir da Constituição de 1934 (Andrade, 2014). Na Constituição seguinte, de 1946, esse continuou sendo o assunto mais discutido (Oliveira \& Penin, 1986). E, no período da ditadura militar (1964-1985), o Ensino Religioso se manteve nas escolas públicas (VALENTE, 2018, p. 114).

Nesse período houve grande repressão a manifestações religiosas minoritárias (MAGGIE, 1986, apud MARIANO, 2011).

A partir da fundação da Organização das Nações Unidas, com a aprovação da Declaração Universal dos Direitos Humanos em 1948, o mundo ocidental tem um novo impulso, pois esse documento assinado por todos os países membros traz a obrigatoriedade da liberdade religiosa (JUNQUEIRA, 2011).

Desta forma, o Ensino Religioso passou por diferentes fases na história do Brasil: o caráter confessional, ligado ao catolicismo, vigorou até os anos 1960; passa, então, para um caráter interconfessional, ecumênico, que vigorou até meados dos 1990. Seu foco estava numa perspectiva de sentido, ou centrado na espiritualidade ${ }^{8}$ e, por fim, abordado como fenômeno cultural a partir de 1997 com a nova LDB (BARBOSA, 2013).

No processo constitucional dos anos 1980, que vai levar à abordagem fenomenológica, instituído na redemocratização, grupos minoritários que até então ficavam à margem da política se envolveram fortemente no debate. Assim, com as garantias legais trazidas pela Constituição de 1988, os segmentos religiosos minoritários passaram a ter grande expressão na sociedade brasileira, sobretudo aqueles oriundos do segmento protestante/evangélico (MARIANO, 2011).

Mantém-se o Ensino Religioso no Ensino Fundamental (para crianças de 9 a 14 anos de idade) praticamente nos mesmos moldes das constituições anteriores. Nos anos seguintes, 1995, surgiu o Fórum Nacional Permanente do Ensino Religioso (FONAPER), uma organização da sociedade civil, de cunho ecumênico, articulada nacionalmente com o objetivo de "acompanhar, organizar e subsidiar o esforço de professores, pesquisadores, sistemas de ensino e associações na efetivação do Ensino Religioso como componente curricular". O fórum organizou "Parâmetros Curriculares Nacionais" apresentado ao MEC e, desde então, tem procurado contribuir com a estruturação e a capacitação profissional do campo. Castro e Baldino (2015) afirmam que o

\footnotetext{
${ }^{8}$ Religiosidade para alguns.
} 
FONAPER preconiza um Ensino Religioso como manifestação cultural presente em todos os povos com enfoque na preservação da diversidade, mas destacam a forte disputa no campo.

A Confederação Nacional dos Bispos do Brasil (CNBB), organização ligada à Igreja Católica, também apresentou várias propostas que contribuíram para a estruturação do Ensino Religioso no país, inclusive para a criação da Diálogo, Revista de Ensino Religioso em $1997^{9}$ (BARBOSA, 2013).

Todos esses elementos contribuíram para que na estruturação da Lei de Diretrizes e Bases da Educação - 9.394 (LDB), aprovada em 1996, se mantivesse o Ensino Religioso de caráter confessional e interconfessional; na sequência, porém, em 1997, apresentou-se uma revisão do art. 33 pela Lei 9.475/97, quando ficou estabelecido que o Ensino Religioso se daria nos "horários normais, sendo vetado o proselitismo", de modo a se garantir a manutenção da diversidade cultural Religiosa do Brasil. Desta forma, o Ensino Religioso ganhou um contorno mais pedagógico e menos teológico (idem). Garantindo-se, também, que os sistemas de ensino regulamentem a estruturação dos conteúdos - que devem ser pactuados com a sociedade -, bem como quanto a habilitação dos docentes.

Em 1998 o Conselho Nacional de Educação (CNE), por meio da Resolução 02/98, reconheceu o componente curricular Ensino Religioso como área de conhecimento; em 2008 ocorreu o Acordo Brasil-Santa Sé, que estabelece o Ensino Religioso confessional; em 2010 (CNE/CEB, 04 e 07) institui as Diretrizes Curriculares Nacionais Básicas, que mantém o Ensino Religioso como área de conhecimento; em 2010 a PGR entra com uma ADI 4.439, questionando o acordo no que diz respeito ao Ensino Religioso confessional; em 2016, o CNE, em convênio com a Organização das Nações Unidas para Educação, Ciência e Cultura (CNE-UNESCO), lançou os Materiais Didáticos para o componente Curricular Ensino Religioso (Brasil, 2016). Tais princípios centram-se num Ensino Religioso não-confessional que valorize as culturas e o respeito à alteridade, elementos ratificados com a aprovação, em 2017, da Base Nacional Curricular Comum (BNCC) que segue a mesma lógica não-confessional. Em 2017 o STF julga a ADI 4.439 como improcedente.

\section{ENSINO RELIGIOSO E A DISPUTA PELO MODELO DE LAICIDADE}

\footnotetext{
${ }^{9}$ A publicação foi encerrada em 2015 (Junqueira, 2019).
} 
No Pacto Federativo adotado no Brasil, os diferentes entes têm responsabilidades distintas, cabendo à União a garantia da manutenção de uma unidade nacional, visto ser a educação um bemcomum, cabendo aos Estados a regulamentação específica (Colabora, 2019). No âmbito do Ensino Religioso há uma divisão entre Estados e Municípios, visto que se trata de Ensino Fundamental havendo diferentes variações. Existe uma sobreposição entre Estados e Municípios no tocante ao ensino fundamental, assim, ambos os entes federativos mantêm escolas, mesmo elemento existindo entre a União e os Estados no tocante ao ensino médio.

Nesta autonomia, o Ensino Religioso Confessional teve aprovação e pode ser praticado nas escolas públicas do Estado do Rio de Janeiro (Decreto $\mathrm{n}^{\circ} 3.459 / 2000$ ), fato que se desdobrou nas Orientações Básicas para Ensino Religioso nas Escolas Estaduais (Rio de Janeiro, s.d.) ${ }^{10}$.

Outros Estados da Federação ${ }^{11}$ também possuem parâmetros sobre o assunto; alguns, entretanto, funcionam apenas com as diretrizes do MEC. Dentre os Estados que possuem orientação específica situam-se: Santa Catarina, com a Proposta Curricular de Santa Catarina: Implementação do Ensino Religioso (Santa Catarina, 2001); Paraná com Diretrizes Curriculares da Educação Básica Ensino Religioso (Paraná, 2008); Minas Gerais com Ensino Religioso (CBC) Currículo Básico Comum do Ensino Fundamental (Minas Gerais, 2014); Pernambuco com Parâmetros Curriculares do Ensino Religioso para o Ensino Fundamental (Pernambuco, 2015), todos possuindo caráter fenomenológico.

A aprovação do "Acordo Brasil-Santa Sé” (Decreto 7.107/10), construído a partir de articulações iniciadas formalmente em 2008, teve desdobramentos imediatos no cenário religioso brasileiro, com a proposição da "Lei Geral das Religiões" (PLC 160/2009) que tramitou no Congresso Nacional. Tal proposta buscava estender os benefícios do acordo católico às demais Religiões $^{12}$. O Acordo foi um marco definitivo para a consolidação da perspectiva de uma laicidade do tipo Igreja-Estado. Giumbelle (2011) destaca que a questão do Ensino Religioso é que proporcionou maior controvérsia, pela proposição do modelo confessional.

\footnotetext{
${ }^{10}$ Cabe destacar a existência de Ação de Inconstitucionalidade contra a referida Lei (ADI 141/00) acolhida parcialmente pelo julgador, ou seja, ficou interditada a contração de professores remunerados pela disciplina.

${ }^{11}$ A cidade de São Paulo não oferece o Ensino Religioso e no Estado apenas 43 escolas oferecem a disciplina. $(O$ Globo Online, 29/09/2017) disponível em https://oglobo.globo.com/sociedade/educacao/em-sp-maioria-dasinstituicoes-nao-tem-ensino-religioso-21885881 acessado em 07/08/2018.

12 Arquivado em 21 de dezembro de 2018 com o final da legislatura.
} 
Os 20 artigos [do Acordo Brasil - Santa Sé] tratam de assuntos diversos: representação diplomática; personalidade jurídica das instituições eclesiásticas; integração ao patrimônio histórico, artístico e cultural; proteção de lugares de culto; assistência espiritual em prisões e outras instituições de internato (exceto Forças Armadas, cujo regime já é objeto de outro Acordo); reconhecimento de títulos acadêmicos; instituições de ensino e seminários; Ensino Religioso em escolas públicas; efeitos civis do casamento religioso; segredo do ofício sacerdotal; imunidade tributária; situação trabalhista de sacerdotes e religiosos; concessão de visto para estrangeiros. Entre os itens constantes do texto do Acordo, provavelmente o que desperta maior controvérsia é o do Ensino Religioso em escolas públicas, tema do art. 11. (GIMBELLE, 2011, p. 119).

Selles, Dorvillé e Pontual (2016, p. 876), citando Davilla (2006), destacam que desde que a primeira constituição republicana, fundada sob o ideário liberal, proibiu-se o Ensino Religioso nas escolas oficiais; os setores eclesiásticos católicos passaram a se organizar para "restaurar a Igreja e seus valores na vida pública brasileira e na educação em particular”.

Assim, esse preocupante cenário levou a Procuradoria Geral da República (PGR), em 2010, a entrar no Supremo Tribunal Federal (STF) com uma Ação Direta de Inconstitucionalidade (ADI 4439/2010):

Na ação, a PGR pede que seja conferida interpretação conforme a Constituição Federal ao dispositivo da Lei de Diretrizes e Bases da Educação - LDB (caput e parágrafos $1^{\circ}$ e $2^{\circ}$, do artigo 33, da Lei 9.394/1996) e ao artigo 11, parágrafo $1^{\circ}$ do acordo firmado entre o Brasil e a Santa Sé (promulgado por meio do Decreto 7.107/2010) para assentar que o Ensino Religioso nas escolas públicas não pode ser vinculado a religião específica e que seja proibida a admissão de professores na qualidade de representantes das confissões religiosas. Sustenta que tal disciplina, cuja matrícula é facultativa, deve ser voltada para a história e a doutrina das várias religiões, ensinadas sob uma perspectiva laica. (BRASIL, STF, Notícias, 2017).

O STF promoveu em 2015 Audiência Pública convidando várias entidades a manifestaramse sobre a questão. Diversas entidades afirmaram ver riscos à laicidade do Estado, apresentando elementos materiais para apoiar suas análises, entre elas destaca-se o Instituto de Bioética, Diretos Humanos e Gênero (ANIS) que apresentou uma análise sobre qualidade do material didático (não padronizado) oferecido para o Ensino Religioso. A entidade salientou tratar-se de material tendencioso à promoção de intolerância religiosa/social. O Observatório da Laicidade da Educação (OLE), por sua vez, “apontou que 70\% das escolas públicas de ensino fundamental ministravam aulas de Ensino Religioso, sendo que, desse universo, 54\% confessaram exigir presença 
obrigatória nas aulas e 75\% não ofereciam atividades para alunos que não queriam assistir a essas aulas" (OLE, s.d.).

Após longa tramitação (2010-2018) o STF indeferiu a solicitação da PGR, portanto, ficou facultado o Ensino Religioso Confessional no país.

Para compreender melhor a questão, que enfatiza a disputa entre dois modelos de laicidade (Igreja e Estado e Igreja-Estado), serão analisados o voto do relator, Ministro Luiz Roberto Barroso, e o voto divergente do Ministro Alexandre de Morais.

O relator apresentou seu voto favorável à ação da PGR, afirmando que "o modelo nãoconfessional é o único capaz de assegurar o princípio da laicidade" (BARROSO, 2017, p. 2). A exposição é fundamentada amplamente em conteúdo de autoridades acadêmicas, jurídicas e sociais, dialogando com o documento (CNE-UNESCO), contrapondo-se, portanto, ao Acordo Brasil-Santa Sé. Afirmando, também, a separação entre o público e o privado, "é certo que a modernidade trouxe, efetivamente, a secularização, a laicidade do Estado e a separação entre ciência e fé, com o deslocamento da religião, predominantemente, para o espaço privado" (BARROSO, 2017, p. 7).

$\mathrm{Na}$ defesa de sua tese, o relator trata o paradoxo constitucional que é o Ensino Religioso em si, afirmando que as modalidades confessional ou interconfessional (ecumênico) são impróprias à escola pública, pois "aproximam, em alguma medida, as ordens estatal e religiosa" (BARROSO, 2017, p. 14), pois

Quando se permite que alunos recebam instrução religiosa de uma ou várias religiões dentro das escolas públicas, torna-se inevitável a identificação institucional entre o Estado, que oferece o espaço público da sala de aula, e as confissões, que definem os conteúdos a serem transmitidos. A violação fica ainda mais nítida nos casos em que se exige que os professores da disciplina sejam representantes religiosos ou pessoas credenciadas por Igrejas e, ao mesmo tempo, se admite que sejam remunerados pelo Estado, em contrariedade à vedação expressa no art. 19, I, da Constituição. (BARROSO, 2017, p. 15)

Apresenta, também, fundamentos operacionais enfatizando a impossibilidade de o Ensino Religioso contemplar "todas as confissões de fé", dada a diversidade de crenças presente no país; desta forma, "apenas as religiões majoritárias na sociedade brasileira (como as católicas e evangélicas) têm capacidade de credenciar e formar professores suficientes para atender a todas as escolas públicas. A consequência é a quebra da neutralidade pelo Estado" (BARROSO, 2017, p. 16). Além disto, apresenta casos julgados na Corte Europeia de Direitos Humanos (CEDH) que 
apresentam claras violações de direitos com o Ensino Religioso confessional (BARROSO, 2017, p. 23).

Destaca, também, a síntese da Audiência Pública realizada que contou com 31 participantes, sendo 19 de entidades $(61 \%)$ da sociedade civil, e 12 (39\%) de entidades religiosas. Destes, 23 defenderam a procedência da ação, 74\% dos presentes (BARROSO, 2017, p. 18).

Por fim, ao defender o Ensino Religioso não confessional, defende-se também que haja parâmetros nacionais a fim de ser garantida a neutralidade em todo o território nacional.

$\mathrm{O}$ voto divergente (vencedor) apresentado pelo Ministro Alexandre de Morais traz com clareza os problemas apresentados no que tange às divergências entre os conceitos de laicidade que vigoram no país, fato que se apresenta como paradoxal entre o público e o privado.

$\mathrm{O}$ voto começa afirmando como premissa "a importância da interdependência e complementariedade das noções de Estado Laico e Liberdade de Crença e Culto", sendo este o argumento chave de toda a formulação. Chama atenção, também, para a complexidade da temática que envolve a liberdade "sob a luz da tolerância e diversidade de opiniões" (MORAIS, 2017, p. 2). Sob essa ótica, o voto divergente segue fazendo uma crítica à dubiedade da tolerância, que vem sendo praticada "relacionada à liberdade de manifestação de concepções políticas, ideológicas, de gênero (...) e censura prévia à livre manifestação de concepções religiosas” (MORAIS, 2017, p. 3). E "não há como negar que o pedido da presente ação pretende limitar o legítimo direito subjetivo constitucional do aluno que já possui religião ou de seu pai/responsável em matricularse no Ensino Religioso de sua própria confissão" (MORAIS, 2017, p. 3).

Aprofunda-se numa crítica a "determinados grupos” (não qualificados) destacando o caráter facultativo, não obrigatório do Ensino Religioso:

Paradoxal que pareça, alguns grupos que auxiliaram as minorias a conquistar legítima e corretamente o direito de liberdade de expressão de suas ideias e convicções, inclusive em salas de aula e dentro de currículos de matérias de matrícula obrigatória, pretendem impor forte censura prévia às opiniões religiosas diversas, ao pleitearem um conteúdo neutro e meramente descritivo de religiões, em uma impensável "doutrina religiosa oficial", criada artificialmente pelo Poder Público (MORAIS, 2017, p. 4).

Defende o Ensino Religioso confessional em respeito à laicidade, conforme previsto na Constituição (art. 210), sendo este o fulcro de toda a argumentação: 
Portanto, a partir do respeito ao Estado Laico, da interpretação da singularidade da previsão constitucional do Ensino Religioso e em respeito à liberdade religiosa, a definição do núcleo de seu próprio conceito baseado nos "dogmas da fé", inconfundível com outros ramos do conhecimento científico, como história, filosofia ou ciência das religiões, pretendo demonstrar a improcedência da presente ação (MORAIS, 2017, p. 4).

A argumentação vai se aprofundando nessa linha, de modo a se concluir que apenas o Ensino Religioso Confessional é verdadeiramente legítimo, pois a busca de um currículo comum, centrado nas humanidades, violaria o princípio da laicidade, visto que o Estado estaria interferindo no campo religioso, "gerando uma verdadeira miscelânea religiosa estatal (...) uma verdadeira censura à liberdade religiosa" (MORAIS, 2017, p. 6).

Segue-se, então, uma longa exposição sobre a liberdade religiosa, e a importância de o Estado garanti-la. Afirma-se a singularidade do Ensino Religioso, do ponto de vista epistemológico. Afirmando-se, também, que tal singularidade perderia suas características se o ensino for baseado em parâmetros comuns definidos pelo Estado. Se fosse este o caso, o ensino não deveria ser facultativo, mas obrigatório (MORAIS, 2017, p. 9).

Enfatiza-se na sequência a existência de colaboração, relação de complementariedade, do Estado com a Igreja em diferentes âmbitos da sociedade como, por exemplo, na Saúde com as "Santas Casas de Misericórdia" (MORAIS, 2017, p. 11).

Retoma-se uma visão do Ensino Religioso nas diferentes Constituições do país, com foco na preocupação com a temática pelo constituinte na última Constituição do país (1988), destacando-se todo o esforço parlamentar com a questão.

Retoma-se o caráter singular da disciplina afastando-se a possibilidade de docentes de áreas como história, ciências da religião ou filosofia ministrarem a disciplina que caberia apenas ao religioso versado nos fundamentos de sua fé.

O ensino de "Filosofia", "História das Religiões" ou mesmo "Ciência das Religiões" jamais atingiria o núcleo básico do Ensino Religioso, que consiste nos dogmas da fé, por meio da denominada "Teologia revelada", ou seja, a transmissão e aceitação de informações que dependem de um assentimento de vontade pertencente ao domínio exclusivo da fé, inexplicável pela argumentação racional filosófica ou pelo estudo dos acontecimentos relevantes ocorridos no passado histórico da humanidade (MORAIS, 2017, p. 17).

Para exemplificar esse caráter especial da disciplina recorre-se a uma citação de Tomás de Aquino, retomando-se a defesa de que apenas o ensino confessional faz sentido, no tocante à 
disciplina em questão, pois "os alunos que, voluntariamente, pretendam ter o Ensino Religioso católico, querem aprender e absorver esse tópico - o mistério da Santíssima Trindade - da “Teologia revelada", por uma questão de fé; não lhes bastando a mera exposição descritiva de maneira neutra" (MORAIS, 2017, p. 19), seguindo-se de vários exemplos de diferentes confissões de fé, desde a presbiteriana, judaica, anglicana e islâmica.

Encaminhando-se para a conclusão, afirma o voto divergente que não se trata de proselitismo, pois os alunos já são simpatizantes da causa (fé) ensinada. Finalizando, que as diferentes denominações não são neutras em suas afirmações, o que impossibilitaria um Ensino Religioso não-confessional. Havendo, também, a impossibilidade de o Estado definir conteúdos (dirigismo estatal). Para elucidar, recorre a exemplos em Cortes de fora do Brasil, como Alemanha e EUA.

Apresenta, por fim, diretrizes para implementação do Ensino Religioso a partir de "parcerias voluntárias, sem transferência de recursos", enfatizando que tais parcerias já existem na área da Saúde e Penitenciária (MORAIS, 2017, p. 25), sendo esta última - a penitenciária - um exemplo a ser seguido no que diz respeito à metodologia de implantação do Ensino Religioso, visto que ao preso não há obrigatoriedade em ter a assistência religiosa. E assim, com essa análise, a ação foi julgada improcedente.

O plenário ficou divido na questão e o voto revisor foi vitorioso, por seis a cinco.

Analisando os votos à luz dos conceitos de laicidade apresentados, fica evidente que Luiz Roberto Barroso direcionou seu olhar a partir de uma laicidade de separação total Igreja Estado, baseado na legislação infraconstitucional (LDB), bem como nas regulamentações adotadas por vários Estados. Além de apresentar questões logísticas que impossibilitariam a empreitada, assim como as ameaças à diversidade religiosa minoritária.

Por sua vez, Alexandre de Morais fundamentou seu voto com enfoque laicidade Estado-Igreja que, com clareza, apresentou existir no país, a partir da ilustração da colaboração entre a Igreja e o Estado, em diferentes âmbitos sociais, marcadamente na Saúde e no Sistema Prisional, o que evoca, também, o conceito de laicidade aberta. Em seu voto, entretanto, não se ateve nem às questões logísticas, centrando-se nos direitos individuais que garantem a liberdade de escolha a partir da confissão de fé já professada pela família o que, favorece os grupos majoritários, destacando, por fim, que o modelo pretendido pelo relator, e estruturado nos encaminhamentos 
adotados até então, constituem problemática para o campo, visto que identifica em tais proposições um encaminhamento para um tipo de "religião de estado".

\section{CONSIDERAÇÕES FINAIS}

Neste artigo procurou-se abordar elementos básicos sobre o campo religioso no Brasil, de modo a contribuir para a discussão sobre o modelo de laicidade praticado no país. A proposta se deu a partir da análise dos votos do relator e revisor no Supremo Tribunal Federal na disputa sobre o Ensino Religioso Confessional, em função da Ação Direta de Inconstitucionalidade (ADI 4.439/17).

Iniciou-se pela reflexão sobre o posicionamento do Brasil no tocante às crenças religiosas e os conceitos básicos que permeiam o campo, de modo a situar o leitor no referencial utilizado, bem como destacar a importância do tema para a sociedade brasileira.

Analisou-se a implementação da laicidade nas democracias, a partir da emersão do secularismo, pela separação das coisas do Estado (coisa pública) que se concretizam no Direito (lei); das coisas da Religião (coisa privada), onde se situa a Moral (costumes).

A laicidade é uma característica do Estado democrático, onde se valorizam e harmonizam três princípios: $1^{\circ}$ ) a liberdade de consciência; $2^{\circ}$ ) autonomia da política em relação à religião; $3^{\circ}$ ) ausência de discriminação na diversidade religiosa.

Neste cenário, enfatiza-se a proteção da dignidade da pessoa humana, a partir de seu valor intrínseco, cuja autonomia a remete a características ontológicas (internas) que, necessariamente, precisam ser reconhecidas externamente pela sociedade, que, ao mesmo tempo, a reconhece e o limita em função dos parâmetros comunitários que precisam ser contemplados pelo Estado (LOURENÇO e GUEDES, 2017).

Esta contemplação, ou harmonização, pode ser "neutra" com a total ausência do Estado nas questões religiosas; ou "imparcial” com o Estado atuando para manter o princípio da harmonia, ou seja, impedindo que grupos hegemônicos possam interferir em grupos minoritários.

A partir do modelo de laicidade adotado pelo Estado: a) Laicidade com Igreja de Estado, ou seja, o Estado afirma uma confissão de fé oficial, mas respeita as demais confissões; b) Laicidade Igreja-Estado, onde há uma relação de complementariedade entre ambos; c) Laicidade 
Igreja e Estado, onde há uma separação total entre essas esferas. Do ponto de vista social, ainda, a laicidade pode ser também: d) aberta, onde se enfatiza a complementariedade entre a Igreja e o Estado; e) intransigente, onde se manifesta uma postura hostil em relação à religião.

Ao longo da história do Brasil, o Ensino Religioso sempre esteve presente, com raros momentos de exceção. Como se viu, essa perspectiva se iniciou com a confissão católica, ainda no período colonial, que perdurou por vários séculos, mantendo, ainda hoje, elementos presentes em instituições públicas, como os crucifixos nas paredes das instituições brasileiras.

Cecchetti e Santos (2018) apresentam, o que se pode, talvez, denominar de uma sempre presente pressão da Igreja Católica para a reintrodução do Ensino Religioso Confessional, a partir da Primeira República, reafirmado recentemente com o Acordo Brasil-Santa Sé.

Após o período confessional, seguiu-se um período ecumênico, onde religiões de matrizes semelhantes compartilharam valores.

Na Constituição de 1988 a formalização da separação entre o Estado e a Igreja é clara no art. 19; todavia, há elementos que criam o que se poderia denominar de paradoxo de colaboração, dentre eles está o Ensino Religioso previsto no art. 210, como disciplina facultativa no Ensino Fundamental. Ao longo da regulamentação desse princípio a partir da LDB, 1996, o Ensino Religioso vem sendo abordado pela vertente cultural (revisão do art. 33), não confessional.

A construção dessa última perspectiva vem sendo feita desde meados do século XX, a partir da estruturação de Programas de Ciências da Religião, que contribuíram para a qualificação do campo que, ainda que sob o enfoque do cristianismo, teve impacto nos constituintes (Junqueira, 2019) proporcionando os paradoxos observados na Constituição.

Vargas e Pinho $(2015,2016)$, a partir de pesquisa realizada na UFF, ao analisarem o modelo confessional de Ensino Religioso adotado no Rio de Janeiro, concluem que tal modelo apresenta uma série de inconvenientes, o que impossibilita a prática efetiva dessa modalidade de ensino. A principal questão apontada é "a impossibilidade de montar turmas por credos específicos (...) além de haver uma coação indireta que possibilitaria o sectarismo" (2016, pág. 14).

Assim, adoção do modelo Ensino Religioso Confessional, como uma modalidade oficializada pelo STF, traz à tona a disputa existente no modelo adotado no Brasil, bem como os cuidados que deverão ser tomados para que grupos majoritários não ameacem a autonomia dos grupos minoritários. 


\section{REFERÊNCIAS}

ABUMANSSUR, E.S. “Religião e democracia, questões à laicidade do Estado”. In: CRPSP. Laicidade, Religião, Direitos Humanos e Políticas Públicas. São Paulo: CRPSP, 2016. v. 1. (Coleção Psicologia, Laicidade e as Relações coma Religião e a Espiritualidade, 3 v.).

ALVES, R.V.S. "Secularismo, neutralidade e tolerância: uma abordagem conceitual". In: BRASIL. Diversidade Religiosa no Brasil: pesquisas, reflexões e debates. Distrito Federal: Ministério dos Direitos Humanos, 2018.

ALVES, L.A.S.; Junqueira, S. “A elaboração das concepções do Ensino Religioso no Brasil”. In: JUNQUEIRA S. A; WAGNER, R. O Ensino Religioso no Brasil. Coleção Educação Religião, 5. Curitiba: Champagnat, 2011.

BARBOSA, R. D. G. “A prática de Ensino Religioso não confessional nas abordagens da Revista Diálogo”. Relegens Thréskeia - Estudos e Pesquisa em Religião, Curitiba, v. 2, n. 1, p.71-85, 2013.

BERNI, LEV. "Os diferentes usos do termo espiritualidade: na busca por uma definição instrumental para a psicologia”. In: CRPSP. Psicologia, espiritualidade e epistemologias nãohegemônicas. São Paulo: CRPSP, 2016. (Coleção Psicologia Laicidade e as Relações com a Religião e a Espiritualidade).

BRASIL. CNE/MEC. Diretrizes curriculares nacionais para os cursos de licenciaturas em Ciências da Religião. Parecer 12/2018.

STF, Notícias. Suspenso julgamento de ADI sobre Ensino Religioso nas escolas públicas (2017) disponível em http://www.stf.jus.br/portal/cms/verNoticiaDetalhe.asp?idConteudo=356402\&caixaBusca=N acessado em 07/08/2018.

CNE/ UNESCO. Materiais didáticos para o componente curricular Ensino Religioso visando a implementação do artigo 33 da Lei 9.394/96 revisto na Lei 9.475/97, Distrito Federal, 2016.

STF, Notícias: Mais especialistas expõem seus argumentos na audiência pública sobre Ensino Religioso (2015): disponível em http://www.stf.jus.br/portal/cms/verNoticiaDetalhe.asp?idConteudo=293662 acessado em 07/08/2018.

Ministério da Saúde. Política Nacional de Educação Popular em Saúde. 19 de novembro de 2012. Disponível em http://www.crpsp.org.br/diverpsi/arquivos/pneps-2012.pdf. Acessado em 24/07/2018. 
Presidência da República, Secretaria de Direitos Humanos. Plano Nacional de Direitos Humanos - PNDH/3. Disponível em https://www.ohchr.org/Documents/Issues/NHRA/ProgrammaNacionalDireitosHumanos2010.pdf Acessado em 26/07/2018.

Decreto Lei 7.107 de 11/02/2010 - Acordo República Federativa do Brasil e Santa Sé relativo ao Estatuto Jurídico da Igreja Católica no Brasil firmado na cidade do Vaticano em 13/11/2008. Disponível em http://www.planalto.gov.br/ccivil_03/_ato20072010/2010/decreto/d7107.htm Acessado em 10/09/2019.

. Ação Direta de Inconstitucionalidade - ADI 4.439 de 27/09/2017. Disponível em http://portal.stf.jus.br/processos/detalhe.asp?incidente=3926392. Acessado em 03/09/2019.

. Lei Geral das Religiões - Projeto de Lei da Câmara (PLC) 160 de 2009. Disponível em https://www25.senado.leg.br/web/atividade/materias/-/materia/92959 acessado em 06/08/2018.

Lei de Diretrizes e Bases da Educação (LDB) 9.394 de 20/12/1996. Disponível em http://www.planalto.gov.br/ccivil_03/Leis/L9394.htm acessado em 06/08/2018.

. Constituição da República Federativa do Brasil. Distrito Federal: Presidência da República. 1988. http://www.planalto.gov.br/ccivil_03/constituicao/constituicaocompilado.htm Acessado em 23/07/2018.

CASTRO, R. M.M.; BALDINO, J.M. "O processo de escolarização do Ensino Religioso no Brasil” REVER, SP, Ano 15, n. 2, 69-79, jul/dez, 2015.

CECCHETTI, E.; SANTOS, A. V. “O bom combate mineiro e reintrodução do Ensino Religioso Confessional na Primeira República”. In: Anais do XV SEMINÁRIO DE FORMAÇÃO PARA PROFESSORES DE ENSINO RELIGIOSO; III SEMINÁRIO REGIONAL DO ENSINO RELIGIOSO NO ESPÍRITO SANTO, FONAPER/UFES, p. 169-176, 2018. Disponível em https://fonaper.com.br/wp-content/uploads/2020/05/514_.pdf acessado em 30/05/2020.

COLABORA EDUCAÇÃO - MOVIMENTO COLABORA EDUCAÇÃO, Sistema Nacional de Educação e o regime de colaboração entre os entes federados, 2019 disponível em http://movimentocolabora.org.br/wp-content/uploads/2019/06/colabora-sne-texto-sobre-leicomplementar-do-sne-2019-06-28.pdf, acessado em 29/05/2019.

CONCEIÇÃO, J.L.M. Jesuítas na educação brasileira: dos objetivos e métodos até sua expulsão. Educação Pública, 2017. Disponível em http://educacaopublica.cederj.edu.br/revista/artigos/jesuitas-na-educacao-brasileira-dosobjetivos-e-metodos-ate-a-sua-expulsao , acessado em 16/08/2018. 
DECLARAÇÃO UNIVERSAL DA LAICIDADE NO SÉCULO XXI (2006) (Tradução e adaptação BERNI, L.E.V. SP: Ateliê de Pesquisa Transdisciplinar [APTD]) disponível em https://www.academia.edu/34547642/DECLARA\%C3\%87\%C3\%830_UNIVERSAL_DA_LAI CIDADE_NO_S\%C3\%89CULO_XXI_Tradu\%C3\%A7\%C3\%A30_e_Adapta\%C3\%A7\%C3\% A3o_ Acessado em 04/08/2018.

FGV - FUNDAÇÃO GETÚLIO VARGAS. Dicionário de Ciências Sociais. Rio de Janeiro: FGV, 1986.

FONAPER, FÓRUM NACIONAL PERMANENTE DO ENSINO RELIGIOSO. http://fonaper.com.br/

FISCHMANN, R. A. Proposta de Concordata com a Santa Sé e o debate na Câmara Federal. Educ. Soc., Campinas, vol. 30, n. 107, p. 563-583, maio/ago. 2009.

GEERTZ, C. A Interpretação das culturas. Rio de Janeiro: LTC, 2008.

GOLDIN, J.R. Ética, Moral e Direito, 2003. Disponível em

http://www.bioetica.ufrgs.br/eticmor.htm ; acessado em 16/02/2016.

GIUMBELLE, E. Acordo Brasil-Santa Sé e as Relações entre Estado e Religião. Ciencias Sociales y Religión/Ciências Sociais e Religião, Porto Alegre, ano 13, n. 14, p. 119-143, setembro de 2011.

GRITTI, R. La Política do Sacro: laicitá, religione, fondamentalism nel mondo globalizado. Milan: Guerini e Associati, 2004.

JUNQUEIRA, S. “A presença do Ensino Religioso no contexto da Educação”. In: JUNQUEIRA, S. A,; WAGNER, R. O Ensino Religioso no Brasil. Curitiba: Champagnat, 2011. (Coleção Educação Religião, 5).

JUNQUEIRA, S. A. R. “Quatro Estações para o Diálogo: quarenta anos de contribuição do Programa de Ciências da Religião da PUC-SP para o Ensino Religioso". REVER, São Paulo, v. 19, n.2, p.161-176, mai/ago, 2019.

. “Ciências da Religião aplicada ao Ensino Religioso". In: PASSOS, J.D.; USARSKI, F. (org.) Compêndio de Ciências da Religião. SP: Paulinas/Paulus, 2013.

LOURENÇO, C.S.; GUEDES, M.S.B. O STF e o Ensino Religioso em escolas públicas: pluralismo educacional, laicidade estatal e autonomia individual. Revista de Investigações Constitucionais, Curitiba, v. 4, n.3, 145-165, set/dez.2017.

MAGGIE, Y. "O Medo do Feitiço - verdades e mentiras sobre a repressão às religiões mediúnicas. In: Religião e Sociedade, v. 13, n. 1, 72-86, 1986. 
MARIANO, R. "Laicidade à Brasileira: Católicos, pentecostais e laicos em disputa na esfera pública”. Civitas, Porto Alegre, v. 11, n.2, p. 238-258, maio-ago. 2011

MENESES, J.M. F. O retorno dos jesuítas ao Brasil: A República e a Educação na Bahia. (2013) Disponível em http://sbhe.org.br/novo/congressos/cbhe7/pdf/07\%20HISTORIA \%20DAS\%20INSTITUICOES\%20E\%20PRATICAS\%20EDUCATIVAS/O $\% 2$ ORETORNO\%20DOS\%20JESUITAS\%20AO\%20BRASIL\%20A\%20REPUBLICA\%20E\%20A \%20EDUCACAO\%20NA\%20BAHIA.pdf acessado em 16/08/2018.

MICHAELIS 2000. Moderno Dicionário da Língua Portuguesa. São Paulo: Melhoramentos, 2000.

MINAS GERAIS. Ensino Religioso (CBC) Currículo Básico Comum do Ensino

Fundamental. Secretaria de Estado de Educação de Minas Gerais. 2014.

https://www.trescoracoes.mg.gov.br/docs/seduc/cbc-anos-finais-ensino-religioso.pdf acessado em 29/05/2020.

MORIN, E. Complexidade e ética da solidariedade. In: CASTRO, G.; CARVALHO, E.A.; ALMEIDA, M.C. (org.). Ensaios de Complexidade. Natal: EDUFRN, 1997.

OLE - OBSERVATÓRIO DA LAICIDADE NA EDUCAÇÃO. Estado laico, leigo ou secular? (s.d.) Disponível em http://www.edulaica.net.br/artigo/8/conceitos/estado-laico-leigo-ousecular/ acessado em 04/08/2018.

Decisão do STF sobre o Ensino Religioso: quem ganhou e quem perdeu? (s.d.B) Disponível em http://www.edulaica.net.br/artigo/1272/concordata/concordatabrasilvaticano/dimensao-juridica/decisao-do-stf-sobre-o-ensino-religoso-quem-ganhou-e-quemperdeu/ acessado em 06/082018.

. Manifesto Público: laicidade e educação pública: em defesa da aplicação integral dos limites constitucionais ao Ensino Religioso nas escolas públicas brasileiras. De 15 de junho de 2015. Disponível em http://www.edulaica.net.br/uploads/arquivo/MANIEFESTO_LAICIDADE_E_EDUCACAO_PU BLICA.pdf acessado em 06/08/2018.

ORO, A.P. A Laicidade no Brasil e no Ocidente: algumas considerações. Civitas, Porto Alegre, v. 11, n. 2, p. 221-237, maio-ago. 2011.

OKIN, S.M. Gênero, o público e o privado. Estudos Feministas, Florianópolis, 16(2): 440, maio-agosto/2008.

PAIVA, J.G. Laicidade, Psicologia, Religião e Direitos Humanos. In: CRPSP. Laicidade, religião, direitos humanos e políticas públicas. São Paulo: CRPSP, 2016. v.1. (Coleção Psicologia, Laicidade e as Relações coma Religião e a Espiritualidade, 3 v.). 
O Estado e a educação religiosa: observações a partir da Psicologia. Psicologia: teoria e pesquisa. jan-abr 2006, v. 22, n. 1, p. 063-068.

PARANÁ. Secretaria de Estado da Educação. Diretrizes Curriculares da Educação Básica Ensino Religioso, 2008. Disponível em http://portaldoprofessor.mec.gov.br/storage/materiais/0000014238.pdf acessado em 07/08/2018.

PERNAMBUCO. Secretaria de Educação. Parâmetros Curriculares do Ensino Religioso para o Ensino Fundamental. 2015

http://www.educacao.pe.gov.br/portal/upload/galeria/4171/Par\%C3\%A2metros\%20Curriculares \%20de\%20Ensino\%20Religioso_atualizado.pdf acessado em 29/05/2020.

PINHO, L.G.; Vargas, E F M. "Ensino Religioso no Estado do Rio de Janeiro: Conceitos, História e Legislações”, Educação temática digital, Campinas, SP, v. 17, n. 2 p.308-327, maio/ago. 2015. Disponível em

https://www.researchgate.net/publication/318976756_Ensino_religioso_no_estado_do_Rio_de_J aneiro_conceitos_historia_e_legislacoes Acessado em 29/05/2020.

PHILIP, W. O Livro ilustrado das religiões. São Paulo: Publifolha, 2000.

RIO DE JANEIRO. Orientações básicas para Ensino Religioso nas escolas estaduais. Disponível em http://www.edulaica.net.br/uploads/arquivo/orientacoes\%20rj.pdf acessado em 07/08/2018.

Decreto 3.459 de 14 de setembro de 2000: dispõe sobre o Ensino Religioso confessional na Rede Pública do Rio de Janeiro. Disponível em http://alerjln1.alerj.rj.gov.br/contlei.nsf/e9589b9aabd9cac8032564fe0065abb4/16b2986622cc9df f0325695f00652111? OpenDocument acessado em 14/8/2018.

RIOS, R.R.; Silva, R.; REDADORI, A.H.; VIDOR, D. M. Laicidade e Conselho Federal de Psicologia: Dinâmica Institucional e Profissional em Perspectiva Jurídica. Psicologia: Ciência e Profissão. v.37 n.1, 159-175, jan/mar, 2017.

RIVERA, P.B. Pluralismo Religioso e Secularização: Pentecostais na periferia da cidade de São Bernardo do Campo no Brasil. Revista de Estudos da Religião, pp. 50-76, mar/2010.

RIZZARDO, R. O Estado é laico e você é leigo. Disponível em CNBB http://www.cnbb.org.br/o-estado-e-laico-e-voce-e-leigo/ (16/07/2010), acessado em 4 de agosto de 2018.

RUIC, G. Os 20 países mais religiosos do mundo (e os 20 menos). Revista Exame Online, 13 de abril de 2015. Disponível em https://exame.abril.com.br/mundo/os-20-paises-mais-religiososdo-mundo-e-os-20-menos/ Acessado em 23/07/2018. 
SANTA CATARINA. Proposta curricular de Santa Catarina: implementação do Ensino

Religioso. Secretaria de Estado da Educação e do Desporto, 2001.

http://www.sed.sc.gov.br/documentos/ensino-89/proposta-curricular-156/1998-158/disciplinas-

curriculares-232/4628-pcsc-implementacao-er/file acessado em 29/05/2020

SARMENTO, D. “O Crucifixo nos Tribunais e a Laicidade do Estado”. Revista Eletrônica PRPE, maio de 2007.

SECO, A.P.; AMARAL, T.C.I. Marquês de Pombal e a Reforma Educacional Brasileira (s.d.) Disponível em

http://www.histedbr.fe.unicamp.br/navegando/periodo_pombalino_intro.html\#_ftn1 Acessado em 16/08/2018.

SELLES, S.E.; DORVILLÉ L.F.M.; PONTUAL, L.V. Ensino Religioso nas Escolas Estudais do Rio de Janeiro: Implicações para o Ensino de Ciências e Biologia. Ciênc. Educ., Bauru, v. 22, n. 4, p. 875-894, 2016.

SIMON, M. As Missões dos 7 Povos. 4.ed. Santo Ângelo: FuRI, 2017.

SILVA, J. O Estado Laico na Constituição Brasileira. In: BRASIL. Diversidade religiosa no Brasil: pesquisas, reflexões e debates. Distrito Federal: Ministério dos Direitos Humanos, 2018.

VALENTE, G.A. Laicidade, Ensino Religioso na Escola Pública Brasileira: Questionamentos e Reflexões. Pro-Posições, v. 29, n.1, p.107-127. jan-abr, 2018.

VARGAS, E. F. M.; PINHO, L. G. "Ensino Religioso Confessional no Rio de Janeiro: Incompatibilidade entre a Lei 3.59/00 e a Realidade na Administração Escolar”. Anais do XIII Encontro Nacional de História Oral: UFRS - Associação Brasileira de História Oral. 01 a 04 de maio de 2016. Disponível em https://www.encontro2016.historiaoral.org.br/resources/anais/13/1461871069_ARQUIVO_Text ocompletorevisadocodinsc4294971.pdf acessado em 29/05/2020.

VÁZQUEZ, A.S. Ética. Rio de Janeiro: Civilização Brasileira, 1997. 